\section{Kognat Bahasa Jawa dan Bahasa Bali: Sebuah Studi Kontrastif}

\author{
I Dewa Putu Wijana \\ Linguistics Master Program, \\ Universitas Gadjah Mada \\ idp_wijana@yahoo.com
}

\title{
ABSTRACT
}

This article is about a contrastive analysis of Javanese and Balinese cognates, the two genetically related local languages spoken in Indonesia. Using data extracted from a Javanese dictionary and compared with their Balinese equivalents retrieved from my intuitions as a Balinese native speaker, it is found that even just from $A$ and B entries, the two languages share a lot of cognates which are hypothetically derived from theirs descending language, proto language, Austronesian. In spite of cognates that have identically semantic contents and formal appearances, there also ones that have different phonological forms and semantic senses.

Keywords: contrastive; cognate; proto language

\section{PENDAHULUAN}

Dalam perbincangan yang tidak formal dengan orang Jawa terutama yang baru saja saya kenal, sejak pertama kali saya datang ke Pulau Jawa pada akhir tahun 1975 hingga sekarang, mereka selalu saja memiliki kesan bahwa Bahasa Jawa dan Bahasa Bali memiliki banyak persamaan. Oleh karena itulah, mereka sering memiliki kesimpulan, bahwa banyaknya persamaan itulah yang menyebabkan saya cepat dapat menguasai Bahasa Jawa. Mereka sama sekali tidak menelisik lebih jauh bagaimana perjuangan dan usaha keras saya di dalam menguasai Bahasa Jawa ini. Misalnya mereka tidak tahu, bahwa sejak menjadi mahasiswa saya selalu berusaha berkomunikasi dengan Bahasa Jawa, bergaul dengan orang-orang Jawa, dan jarang bergaul dengan sesama mahasiswa dari Bali. Bahasa Jawa dan Bahasa Bali, seperti lumrahnya Bahasa (langue) yang berbeda adalah dua sistem Bahasa yang satu sama lain tidak saling paham (mutually unintelligible). Sebagai sebuah Bahasa yang berbeda jumlah kognat (cognate)-nya, tentu jauh lebih sedikit (kurang dari) 20\% dari seluruh leksikon yang ada (Multamia 1993: 145). Akan tetapi, kesan yang ditimbulkan oleh rekan-rekan penutur Bahasa Jawa itu tidaklah sama sekali tidak beralasan setelah saya mencoba-coba mendaftar jumlah kognat Bahasa Jawa dan Bali melalui penelusuran kamus Bahasa Jawa dan membandingkannya dengan kognat Bahasa ibu saya. Hanya dari 2 alfabet entri saja, yakni A dan B saya sudah menemukan tidak kurang dari 130 buah kognat, dan dari pengamatan yang lebih jauh kognat-kognat itu telah menunjukkan cukup banyak variasi bentuk dan makna yang akan menjadi pusat perhatian makalah ini, yang selama ini belum pernah diungkapkan secara serius oleh para linguis, khususnya oleh para ahli bahasa, baik secara komparatif atau kontrastif.

\section{TINJAUAN PUSTAKA}

Studi tentang berbagai aspek Bahasa Jawa dan Bahasa Bali dari berbagai tatarannya agaknya telah dilakukan oleh berbagai ahli kedua Bahasa secara relatif cukup lengkap. Tidak hanya tinjauan secara formal telah dilakukan. Studi-studi yang berwawasan sosiolinguistik dan pragmatik pun sudah berlimpah ditemukan. Karya Tata Bahasa Baku Bahasa Jawa (Subroto, Soenardji, and Sugiri 1991) dan Kajian Morfologi Bahasa Jawa (Uhlenbeck 1982) merupakan dua di antara berbagai studi bahasa Jawa secara formal. Kajian-kajian secara sosiolinguistik telah pula banyak dilakukan, seperti karya Supardo (1995), Poedjosoedarmo et al. (1979), Suhardi et. Al. (1985). dsb. Khusus yang berkenaan dengan dialektologi, Bahasa Jawa dan Bahasa Bali boleh dikatakan tidak ada lagi yang dapat diteliti. Karya-karya dialektologi Jawa sudah sangat berlimpah. Misalnya di sini dapat disebutkan karya Katrini (2002) tentang Bahasa Jawa di Jawa Tengah Bagian Timur, Laksono (1995) tentang Bahasa Jawa di Mojokerto, Soetoko et al. (1984) tentang Bahasa Jawa di Kabupaten Jember. Sementara itu, 
dialek-dialek Bahasa Bali sudah pula dijadikan topik disertasi oleh Bawa (1983). Sementara itu sejauh ini belum ditemukan studi komparatif atau kontrastif tentang Bahasa Jawa dan Bahasa Bali meskipun studi komparatif tentang bahasa-bahasa di Indonesia memang telah banyak juga dilakukan. Misalnya Fernandez (1996) tentang kekerabatan Bahasa di Flores, Budasi (2007) tentang kekerabatan Bahasa di Sumba.

\section{LANDASAN TEORI}

Sebuah Bahasa, lebih-lebih yang digunakan jumlah penutur yang besar dan beragam, serta berpindah-pindah akan selalu berubah dan berkembang sesuai dengan tuntutan pemakainya. Semula perbedaan itu sedikit, tetapi lama-kelamaan seiring berjalannya waktu dan keterpisahan yang cukup lama (ratusan tahun), satuan-satuan yang semula sama sedikit demi sedikit berubah bentuk maknanya sehingga variasi yang semula bersifat saling faham (mutually intelligible) berubah menjadi sistem yang tidak saling faham (mutually unintelligible) (Parker and Riley 2014: 173; Wardhaugh 1986: 128). Yang semula hanya dialek menjadi Bahasa yang berbeda. Semakin sulit kelompok penutur berhubungan, semakin bertahan perbedaan yang ada. Demikian pula sebaliknya, semakin mudah perhubungan atau interaksi, perbedaan akan semakin kecil. Meskipun Bahasabahasa yang berasal dari rumpun yang sama berpisah dalam waktu yang cukup lama, tetap saja terdapat unsur-unsur leksikal atau unsur gramatikal yang tetap bertahan sehingga memungkinkan para ahli merunut asal-usul dan kekerabatan Bahasa. Perbedaan-perbedaan fonologis yang bersifat teratur dan leksikogramatika dapat diterangkan sehingga secara kuantitatif atau kualitatif Bahasa meso dan Bahasa protonya dapat direkonstruksi. Dengan kerangka teoretis ini dapat diasumsikan bahwa Bahasa Jawa dan Bahasa Bali yang berasal dari rumpun Bahasa yang sama, yakni Austronesia akan memiliki sejumlah kognat yang perubahan bunyinya dapat diterangkan ketaraturannya, dan perbedaan dan kemiripan maknanya dapat dideskripsikan secara sistematis.

\section{METODE}

Data yang disajikan dalam penelitian ini diperoleh dari Kamus Lengkap Jawa Indonesia susunan Sutrisno Sastro Utomo (2007) melalui penelusuran entri berinisial A dan B lalu dipilih yang memiliki padanan yang sama atau mirip baik secara bentuk dan semantik dengan kata-kata Bahasa Bali dengan bantuan pengetahuan dan intuisi penulis sebagai penutur asli Bahasa Bali, dan telah berpuluh-puluh tahun tinggal di Pulau Jawa dan menggunakan Bahasa Jawa sebagai alat komunikasi sehari-hari, terutama dalam situasi informal, serta menggunakan Bahasa Indonesia dalam situasi formal, atau dalam situasi-situasi lain yang mengharuskan. Penelusuran yang dimulai dari kata-kata Bahasa Jawa akan memungkinkan menyebabkan munculnya kognat-kognat lain, baik dalam Bahasa Bali atau Bahasa Jawa sendiri yang mungkin bukan termasuk ke dalam entri A atau B. Misalnya entri bulan Bahasa Jawa akan memunculkan kata bulan dalam Bahasa Bali, dan kata wulan dalam Bahasa Jawa yang termasuk ke dalam entri W. Kesemuanya bermakna 'bulan' dalam Bahasa Indonesia, tetapi ragam yang berbeda. Contoh lain kata ajrih 'takut' dalam entri A Bahasa Jawa menimbulkan padanan dalam Bahasa Bali jerih dalam hubungannya dengan 'ayam yang tak berani bertarung'. Lalu, dalam Bahasa Jawa sendiri muncul padanan jirih 'takut' yang dapat dikenakan pada perasaan manusia. Dengan penerapan metode ini memunghkinkan data-data yang disajikan melampaui batas entri A dan B. Kata-kata yang berpadanan selanjutnya diklasifikasikan menjadi kognat yang berpadanan secara fonologis dan semantik persis sama, kognat yang memiliki perbedaan fonologis, kognat yang memiliki perbedaan semantis. Kognat yang berpadanan secara fonologis, kemudian diklasifikasikan antara perubahan fonologis yang teratur dan perubahan fonologis yang bersifat sporadis. Hanya saja, karena penelitian ini bersifat kontrasitif sinkronik, tidak akan menjadi pertimbangan mana kognat yang muncul lebih dahulu, dan mana kognat yang muncul kemudian. Yang dapat diidentifikasikan hanyalah perbedaan keduanya apakah yang satu lebih pendek dari yang lain, dan sebaliknya. Atau, apakah yang satu maknanya lebih luas atau lebih sempit, bukannya meluas atau menyempit yang menyangkut perubahan diakronik meskipun ada anggapan yang sangat umum sampai sekarang ini bahwa Bahasa Bali berasal dari Bahasa Jawa yang dibawa oleh orang-orang Jawa pada jaman setelah keruntuhan Kerajaan Majapahit. Akan tetapi, relasi historis kedua Bahasa ada kemungkinan terjadi jauh-jauh hari sebelum runtuhnya kerajaan terbesar di Jawa itu.

Penentuan kognat dilakukan dengan terlebih dahulu menyingkirkan bentuk-bentuk korespondensi yang merupakan kata pinjaman dari bahasa asing, terutama dari Bahasa Inggris, Bahasa Arab, dan 
Bahasa Portugis, serta Bahasa Mandarin. Kognat kognat yang ditemukan ditranskripsikan secara fonetis, dengan gloss Bahasa Indonesia yang disajikan secara ortografis.

\section{HASIL PENELITIAN}

Dari pengamatan yang saksama terhadap seluruh data, didapatkan bahwa kognat-kognat Bahasa Jawa dan Bahasa Bali dapat ditinjau dari dua aspek, yakni dari segi bentuk dan dari segi makna. Dari segi bentuk dapat dibedakan kognat yang memiliki bentuk sama, kognat yang memiliki bentuk yang mirip. Dari segi semantik ada kognat yang memiliki makna yang sama dan ada kognat yang memiliki makna yang mirip. Keempat jenis kognat ini akan dibicarakan satu persatu dalam seksi-seksi berikut.

\section{Kognat yang Memiliki Bentuk yang Sama}

Ada cukup banyak kognat Bahasa Jawa dan Bahasa Bali memiliki bentuk fonologis yang sama. Misalnya kata abon 'daging yang disayat', adhi 'adik, adhu?'aduk', agd 'besar', aja?'ajak', alUs 'halus', dsb. Kesemua kognat ini juga memiliki makna yang sama. Sementara itu, leksem-leksem yang memiliki bentuk yang sama, tetapi makna yang jauh berbeda, dan perbedaan itu tidak dapat diterangkan secara sinkronis maupun diakronis dianggap bukan kognat. Misalnya dalam Bahasa Jawa

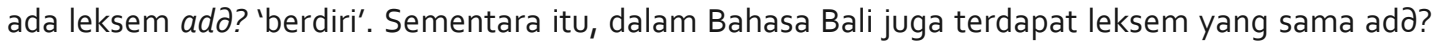
'cium'. Kedua leksem ini memiliki makna yang sama sekali berbeda sehingga kesamaan ini dianggap bersifat aksidental, dan sangat biasa terjadi di dalam "langue" yang berbeda. Contoh yang lain misalnya dapat diperhatikan pada daftar berikut beserta perbedaan glossnya yangv mencolok:

\begin{tabular}{|c|c|c|}
\hline Bahasa Jawa & Bahasa Bali & Gloss \\
\hline adhəp & adhдp & hadap $><$ jual \\
\hline ajag & ajag & liar >< melaju \\
\hline ajd* & ajd & akan $><$ makan \\
\hline badhe & badhe & akan $><$ tempat mayat \\
\hline baja & bajaæ & kerdil $><$ dewasa \\
\hline balӘs & balds & balas $><$ deras \\
\hline
\end{tabular}

Tidak banyak hal yang dapat dibicarakan dalam kaitannya dengan kognat yang memiliki ciri fonologis yang identik ini.

\section{Kognat yang Memiliki Bentuk yang Mirip}

Sejauh yang berhubungan dengan kognat yang memiliki kemiripan bentuk, kognat-kognat ini dapat dibedakan menjadi dua tipe, yakni kognat yang berkorespondensi bunyi dan kognat yang bentuknya lebih singkat atau lebih panjang daripada yang lain.

\section{a. Kognat yang Memiliki Korespondensi Bunyi}

Kognat-kognat yang memiliki korespiondensi bunyi setidak-tidaknya dapat dibeda-bedakan menjadi 2 jenis, yakni kognat yang memiliki korespondensi yang teratur dan kognat yang memiliki korespondensi bunyi yang sporadis. Ada sejumlah korespondensi fonologis yang bersifat teratur, seperti:

1) Korespondesnsi --o dan --d

Sejumlah kata-kata yang merupakan kognat dalam Bahasa Jawa yang berakhir dengan /0/ berkorespodensi dengan / $/$ di dalam Bahasa Bali. Misalnya perhatikan daftar berikut:

\begin{tabular}{|c|c|c|}
\hline Bahasa Jawa & Bahasa Bali & Gloss \\
\hline adityo & adityд & matahari \\
\hline $0 \neq k o$ & $\mathrm{a} * \mathrm{k} \partial$ & angka \\
\hline
\end{tabular}


Kognat Bahasa Jawa dan Bahasa Bali: Sebuah Studi Kontrastif

\begin{tabular}{|c|c|c|}
\hline bojro & bajrd & tombak bermata lima \\
\hline balonjo & bəlanjд & belanja \\
\hline bopo & bapд & ayah \\
\hline boto & batz & bata \\
\hline
\end{tabular}

Dari contoh di atas terlihat bahwa di dalam Bahasa Jawa terjadi harmoni vocal, sedangkan dalam Bahasa Bali fenomena ini tidak terjadi. Fenomena ini mengakibatkan adanya korespondensi: 0--0 dan a--ə. Berikut adalah contoh-contoh yang lainnya:

\begin{tabular}{|c|c|c|}
\hline Bahasa Jawa & Bahasa Bali & Gloss \\
\hline abiyoso & biasd & biasa \\
\hline bathoro & 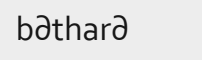 & batara, dewa \\
\hline a*koro & aækard & angkara \\
\hline boyo & buayd & buaya \\
\hline
\end{tabular}

2) Korespondensi --r dan --h, --d

Kognat-kognat yang berakhir bunyi/r/ dalam Bahasa Jawa seringkali berkorespondensi dengan bunyi /h/ atau /d/ dalam Bahasa Bali, seperti terlihat dalam table berikut:

\begin{tabular}{|c|c|c|}
\hline Bahasa Jawa & Bahasa Bali & Gloss \\
\hline Ajar & ajah & ajar \\
\hline 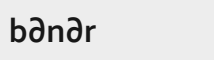 & bənah & benar \\
\hline bubUr & bubUh & bubur \\
\hline pagdr & pagəh & pagar $><$ kuat \\
\hline cungUr & cu: & hidung \\
\hline ulər & uldd & ulat \\
\hline illr & illh & kipas \\
\hline
\end{tabular}

Secara lengkap, inilah agaknya yang disebut dengan hukum /r/, /d/, dan /h/. Ada pula ditemukan

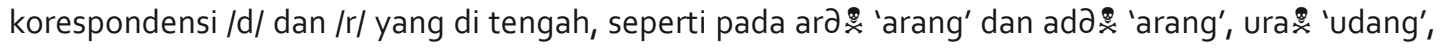
uda: 'udang'.

3) Korespondensi --p, --t, --? dan --b, --d, --g

Dalam Bahasa Jawa standard yang dituturkan oleh penutur-penutur dari daerah Surakarta, dan Yogyakarta, atau mungkin juga penutur-penutur Bahasa Jawa di Jawa Timur, bunyi-bunyi hambat bilabial tak berrsuara /p/, /t/, dan /? yang berdistribusi di akhir kata berkorespondensi dengan ekuivalen bersuaranya, yakni /b/, /d/, dan /g/. Di dalam dialek Bahasa Jawa Banyumas bunyi bersuara ini masih bertahan. Hal ini terlihat dalam table berikut ini:

\begin{tabular}{|c|c|c|}
\hline Bahasa Jawa & Bahasa Bali & Gloss \\
\hline adə? & $\operatorname{ad\partial g}$ & berdiri \\
\hline awa? & awag & ngawur \\
\hline babat & babad & membabat $><$ membeberkan \\
\hline $\operatorname{ta} \approx k \partial p$ & taækəb & tangkup \\
\hline
\end{tabular}




\begin{tabular}{|c|c|c|}
\hline jəba? & jabag & jebak $><$ perangkap \\
\hline 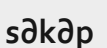 & 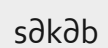 & peram \\
\hline
\end{tabular}

Adanya kesamaan antara Bahasa Bali dengan Bahasa Jawa dialek Banyumas ini mengindikasikan bahwa Bahasa Jawa baru terjadi kemudian setelah Bahasa Jawa kuna masuk ke Bali.

4) Korespondensi w-- dan b--

Bunyi semi vokal /w/ dalam Bahasa Jawa yang berdistribusi di awal kata kerap kali berkorespondensi dengan bunyi /b/ dalam posisi yang sama pada Bahasa Bali. Untuk ini dapat dipertimbangkan kognatkognat yang terdapat pada table berikut:

\begin{tabular}{lll}
\hline Bahasa Jawa & Bahasa Bali & Gloss \\
\hline watu & batu & batu \\
wuklr & buklt & bukit \\
wulan & bulan & bulan \\
wani & bani & berani \\
wayah & wayah & cucu $><$ kakek \\
woco & bacd & baca \\
\hline
\end{tabular}

5) Korespondensi t--, d--, -t-, -d- dan th--, dh--, -th-, -dh-

Karena bahasa Jawa memiliki /t/, /th/, /d/, dan /dh, sedangkan Bahasa Bali hanya mempunyai /th/ dan /dh/, maka /t/dan /d/ dalam Bahasa Jawa yang berdistribiusi di depan dan di tengah akan berkorespondensi dengan/th/ dan/dh/. Untuk ini periksa table di bawah ini:

\begin{tabular}{lll}
\hline Bahasa Jawa & Bahasa Bali & Gloss \\
taji & thaji & bilah tajam dari logam \\
tatu & thathu & luka \\
dadar & dhadhar & cara menggoreng telur \\
dadi & dhadhi & jadi \\
\hline
\end{tabular}

Selain kelima korespondensi yang bersifat teratur di atas, terdapat pula sejumlah korespondonsi yang tidak teratur atau sporadis dengan contoh-contoh yang sangat sedikit, Misalnya korespondensi anatara /i/ dan /e/ serta /w/ dan /y/ pada kata Bahasa Jawa sewu 'seribu' dan Bahasa Bali siyu 'seribu', /h/ dan /w/ pada suhUn 'hormat' Bahasa Jawa dan suwUn 'junjung' Bahasa Bali, /i/ dan /e/ dalam

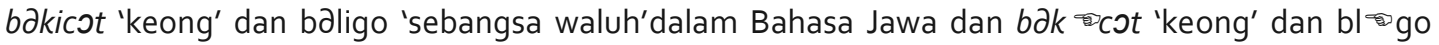
'sebangsa waluh' dalam Bahasa Bali, dsb.

\section{b. Kognat yang Bentuknya Lebih Singkat atau Lebih Panjang}

Kognat kedua bahasa memungkinkan bentuknya lebih pendek atau lebih panjang dari pada yang lain. Pemanjangan dan pemendekan ini disebabkan adanya berbagai prosen linguistik seperti penghilangan atau penambahan bunyi atau suku kata, baik di awal atau di tengah, maupun di akhir leksem, baik karena perubahan fonologis atau karena proses morfologis, seperti afiksasi atau reduplikasi, seperti terlihat dalam table berikut ini:

\begin{tabular}{|c|c|c|}
\hline Bahasa Jawa & Bahasa Bali & Gloss \\
\hline abiyoso & biyasd & biasa \\
\hline ajrlh, jirlh & jrlh, jərlh & takut $><$ takut bertarung \\
\hline adus & mandus & mandi \\
\hline
\end{tabular}


Kognat Bahasa Jawa dan Bahasa Bali: Sebuah Studi Kontrastif

\begin{tabular}{|c|c|c|}
\hline alUm & lumlUm & layu \\
\hline amdrto & martว & hidup \\
\hline ana? & pana? & anak \\
\hline apuro & ampurd & maaf \\
\hline aluwUะ & luwUng & bagus \\
\hline 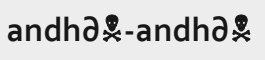 & adhengan & tahi lalat \\
\hline athos & kathos & keras \\
\hline banci & banclh & banci \\
\hline bu^kUs & u※kUs & bungkus \\
\hline
\end{tabular}

Tentu saja yang mana merupakan proses pengurangan dan penambahan belum dapat ditentukan di sini sebelum dapat dipastikan leksem mana yang lebih dahulu muncul.

\section{Aneka Perbedaan Makna Kognat Bahasa Jawa dan Bahasa Bali}

Seperti telah dikemukakan pada 5.1 bahwa kognat-kognat Bahasa Jawa dan Bahasa Bali ada yang memiliki kesamaan bentuk dan makna, dan ada yang memiliki kemiripan makna dilihat dari berbagai aspek. Adapun berkaitan dengan kognat-kognat yang memiliki kemiripan makna perbedaannya dapat berkaitan dengan berbagai hal, seperti perbedaan ragam, perbedaan register, perlawanan arti, perbedaan makna umum dan khusus, dan perbedaan makna asosiatif. Keempat aspek perbedaan ini akan diuraikan dalam seksi-seksi berikut ini:

\section{a. Perbedaan Ragam}

Kognat-kognat Bahasa Jawa dan Bali memiliki kemungkinan dipergunakan dalam ragam bahasa yang berbeda meskipun secara konseptual atau denotatif memiliki makna yang sama. Misalnya kata gдni 'api' dalam Bahasa Jawa digunakan pada ragam biasa atau Ngoko atau sehari-hari, sedangkan ekuivalennya di dalam Bahasa Bali digunakan di dalam ragam Bahasa halus atau Bahasa Bali Singgih. Sebaliknya kata dhahar 'makan' dalam Bahasa Jawa digunakan di dalam ragam halus atau Krama, sedangkan ekuivalennya dalam Bahasa Bali dhaar digunakan dalam ragam biasa Kepara. Contoh lainnya, misalnya kata ak $₫$ 'banyak' di dalam Bahasa Jawa digunakan untuk ragam Ngoko, sedangkan dalam Bahasa Bali kata ini digunakan untuk ragam halus. Untuk ragam halus di dalam Bahasa Jawa digunakan kata kathah 'banyak', sedangkan untuk ragam Bahasa biasa di dalam Bahasa Bali digunakan liu 'banyak'. Yang menarik adalah kata-kata yang mengacu bagian tubuh karena katakata ini berpotensi digunakan untuk makian (periksa Wijana 2014: 79-98). Misalnya kata cangkdm 'mulut' dalam Bahasa Jawa adalah kata kasar (indecent word), sedangkan dalam Bahasa Bali cangkdm adalah leksikon ragam halus. Imbangan cangkdm dalam Bahasa Jawa adalah lambe 'mulut', sedangkan dalam Bahasa Bali digunakan bu $2 U t$. Kata cokor 'kaki' dalam Bahasa Jawa adalah bentuk halus sebagai imbangan dari sikll atau suku 'kaki', sedangkan dalam Bahasa Bali 'cokor' adalah ragam halus, dan imbangannya yang biasa adalah bathls atau bals 'kaki'. Kata asu 'anjing' di dalam Bahasa Jawa adalah kasar, sedangkan dalam Bahasa Bali ragam halus. Adapun imbangannya dalam Bahasa Jawa adalah segawon, sedangkan dalam Bahasa Bali digunakan kulU?.

Perbedaan di antara kognat-kognat itu tidak hanya menyangkut ragam halus, biasa, dan kasar, tetapi sering kali pula berhubungan dengan ragam sastra (literer) dan non-sastra (nonliterer). Misalnya kata luhU \& dan aluwU \&yang bermakna 'bagus' dalam Bahasa Jawa hanya muncul atau digunakan dalam ragam sastra, sedangkan untuk ragam biasa Bahasa ini menggunakan aplk 'baik'. Sementara itu, di dalam Bahasa Bali kata luwUng, atau luUng digunakan untuk ragam sehari-hari Bersama sinonimnya mdlah 'baik'. Dalam Bahasa Jawa kata aran yang hadir Bersama afiksnya ₹arani 'menyebut' adalah tergolong ragam biasa bersama sinonimnya jand ' 'nama'. Akan tetapi, aran dalam Bahasa Bali hanya digunakan dalam ragam sastra yang bermakna 'nama', dan imbangannya dalam ragam biasa adalah adhan 'nama'. Akhirnya walaupun telah ada kata buklt 'bukit' dalam Bahasa Jawa, tetapi kata wuklr 'bukit' juga masih sering terdengar di dalam ragam-ragam sastra. Di dalam Bahasa Bali wuklr tidak dikenal karena yang digunakan hanya buklt. 


\section{b. Perbedaan Register}

Kemungkinan lain, perbedaan makna di antara kognat Bahasa Jawa dan Bali, berkaitan dengan perbedaan bidang pemakaian atau register. Misalnya kata Bahasa Jawa ajrih dan jirih 'takut' secara bertutut-turut digunakan dalam ragam halus dan ragam biasa. Akan tetapi, ekuivalennya dalam Bahasa Bali yakni jrlh datau jorlh 'takut' hanya dapat dikenakan pada ayam. Kata-kata ini agaknya berhubungan dengan register sabung ayam yang sangat populer di Bali (periksa Wijana 2008: 477503). Kata-kata yang menunjuk warna dalam Bahasa Jawa seperti ijo 'hijau', wills 'hijau', biru 'biru', dsb. di dalam Bahasa Jawa digunakan sebagai kata biasa dan kata ragam sastra. Akan tetapi, dalam Bahasa Bali ijo dan wills, dan biru referen yang sama hanya digunakan di dalam register sabung ayam untuk mengacu warna bulu ayam dan kaki ayam. Kata godhe? dalam Bahasa Jawa menunjuk bulu lebat di leher manusia, sedangkan dalam Bahasa Bali mengacu bulu lebat di kaki ayam. Di samping ada kognat-kognat yang sama-sama digunakan untuk register yang sama. Misalnya bandingkan kognat register adu ayam kedua Bahasa.

\begin{tabular}{lll}
\hline Bahasa Jawa & Bahasa Bali & Gloss \\
\hline wiring & Biing & Merah \\
waækas & waækas & Putih campur merah \\
brumbUn & brumbUn & campur, hitam, merah, putih \\
burlk & bulk & putih lurik-lurik hitam \\
sdrawah & sdrawah & putih campur sedikit hitam
\end{tabular}

\section{c. Perlawanan Makna}

Ada sedikit jumlah kognat yang memiliki makna yang berlawanan atau dalam hubungan yang tertentu bertentangan. Misalnya kata amarta maknanya 'hidup', tetapi lama kelamaam seiring berjalannya waktu afiks Bahasa yang menurunkannya \{a-\} mengalami peluluhan sehingga tinggal

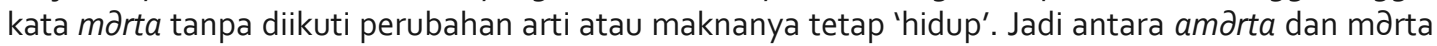
yang seharusnya berlawanan maknanya tetap sama. Fenomena yang sama terjadi pula pada afiks \{nir-\} pada Nirmala 'suci, bersih' perubahannya menjadi mala sering tidak diikuti dengan perubahan makna. Oleh karena itu, sebuah desa di Bali Banyumala sekarang diganti dengan Banyuasri. Mereka tidak menyadari bahwa desa itu dahulu mungkin bernama Banyunirmala. Yang terlihat hanya Banyumala, dan mala artinya 'kotor'. Lain halnya dengan kata nom, atau varian kramanya $n$ m dalam Bahasa Jawa maknanya 'muda. Akan tetapi, ekuivalennya dalam Bahasa Bali anom maknanya

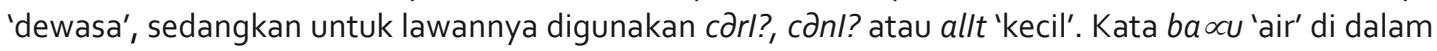
Bahasa Jawa mengacu pada 'air kotor yang telah digunakan untuk mencuci' dalam Bahasa Bali. Sementara untuk air yang biasa digunakan yeh 'air' atau toyd 'air' ragam halus. Hal ini agaknya berkaitan erat dengan ragam halus dan ragam biasa atau kasar dalam 5.3.1.

\section{d. Perbedaan Asosiatif}

Perbedaan makna di antara kognat-kognat dapat pula berkaitan dengan perbedaan yang bersifat asosiatif. Misalnya kata manU? Dalam Bahasa Jawa bermakna 'burung', tetapi di dalam Bahasa Bali manU? mengacu pada referen yang lain 'ayam jantan', tetapi keduanya memiliki hubungan, yakni sama-sama bangsa burung. Kata gedhang dalam Bahasa Jawa bermakna 'pisang', sedangkan dalam Bahasa Bali gedhang adalah 'kates', sama -sama buah. Untuk pisang Bahasa Bali menggunakan kata lain, yakni biu. Kata bawa dalam Bahasa Jawa bereferen 'bawang putih', sedangkan untuk bawang merah digunakan bramba $\approx$. Dalam Bahasa Bali yang merah diungkapkan dengan bawa $\approx$, sedangkan yang putih dengan kдsund. Dalam Bahasa Jawa aeng 'aneh', sedangkan dalam Bahasa Bali 'seram'. Ares adalah 'pangkal batang pisang' di Jawa, sedangkan di Bali keseluruhan batangnya. Babat 'menebang pohon' dalam Bahasa Jawa, di dalam Bahasa Bali babad atau beladbad adalah cerita bermulanya suatu tempat dalam kaitannya dengan tindakan membabat hutan sebelumnya. Bojro dalam Bahasa Jawa adalah 'tombak bermata lima', sedangkan dalam Bahasa Bali adalah 'genta yang berhiaskan tombak bermata lima'. Akhirnya kata gudel 'anak kerbau' dalam Bahasa Jawa, dalam Bahasa Bali godhel adalah anak sapi. 


\section{e. Makna Umum dan Makna Khusus}

Akhirnya perbedaan makna antara kognat-kognat yang ada di kedua Bahasa berkaitan dengan

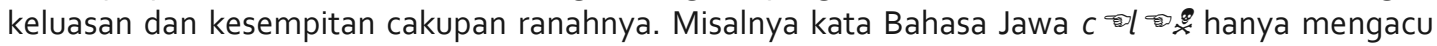
pada 'babi hutan', sedangkan c dalam Bahasa Bali mengacu pada 'babi dewasa pada umumnya'. Awlt dalam Bahasa jawa mengacu pada 'awal', sedangkan Bahasa Bali hanya berhubungan dengan 'leluhur'. Kata ketan 'sejenis beras likat baik yang putih maupun yang hitam, sedangkan dalam Bahasa Bali hanya yang putih saja sebab untuk yang hitam diungkapkan dengan leksem lain, yakni injln 'ketan hitam.

\section{KESIMPULAN}

Sebagai Bahasa yang masih sekerabat, bahasa Jawa dan bahasa Bali tentu saja masih memiliki sejumlah kognat yang memungkinkan digunakan oleh para ahli Bahasa untuk menelusur hubungan genetik kedua bahasa. Kognat-kognat ini memiliki kesamaan atau keserupaan bentuk, baik yang bersifat teratur mapun sporadis. Dengan kesamaan kognat-kognat itu memungkinkan memiliki bentuk fonologis yang identik dengan yang lain dengan makna yang sama atau berubah atau sedikit bergeser. Sementara itu, kata-kata yang memiliki kemiripan bentuk akan menunjukkan berbagai korespondensi, atau bentuknya lebih panjang atau lebih pendek dari yang lain. Akhirnya sejauh yang berkaitan dengan perubahan makna, perbedaan makna ini akan berhubungan dengan perbedaan ragam, perbedaan register, perlawanan makna, perbedaan asosiasi, dan keluasan cakupan makna. Hanya saja, sebelum dapat ditentukan asal-usul Bahasa secara pasti, arah dan wujud perubahan Bahasa tidak dapat dideskripsikan.

\section{REFERENSI}

Bawa, I Wayan. 1983. "Bahasa Bali Di Daerah Propinsi Bali: Sebuah Analisis Geografi Dialek." Disertasi, Depok: Universitas Indonesia. http://lib.ui.ac.id.

Budasi, I. Gede. 2007. "Kekerabatan Bahasa-Bahasa Di Sumba: Suatu Kajian Linguistik Historis Komparatif." Disertasi, Yogyakarta: Universitas Gadjah Mada. http://etd.repository.ugm.ac.id/home/detail_pencarian/36425.

Fernandez, Inyo Yos. 1996. Relasi historis kekerabatan bahasa Flores: kajian linguistik historis komparatif terhadap sembilan bahasa di Flores. Ende, Flores, NTT, Indonesia: Nusa Indah. http://catalog.hathitrust.org/api/volumes/oclc/36131002.html.

Katrini, Yulia Esti. 2002. "Bahasa Jawa Di Jawa Tengah Bagian Timur." Tesis, Yogyakarta: Universitas Gadjah Mada. http://etd.repository.ugm.ac.id/home/detail_pencarian/171532.

Laksono, Kisyani. 1995. "Bahasa Jawa Dialek Jawa Timur Di Mojokerto :: Kajian Geografi Dialek; Buku I." Tesis, Yogyakarta: Universitas Gadjah Mada. http://etd.repository.ugm.ac.id/home/detail_pencarian/17083.

Multamia, R. M. T. Lauder. 1993. Pemetaan Dan Distribusi Bahasa-Bahasa Di Tangerang 38gh. Jakarta: Badan Pengembangan dan Pembinaan Bahasa. http://repositori.kemdikbud.go.id/3344/.

Parker, Frank, and Kathryn Riley. 2014. Linguistics for Non-Linguists. Singapore: Pearson.

Poedjosoedarmo, Soepomo, Th Kundjana, and Gloria Poedjosoedarmo Soepomo. 1979. Tingkat tutur bahasa Jawa. Jakarta: Pusat Pembinaan dan Pengembangan Bahasa, Departemen Pendidikan dan Kebudayaan.

Sastro Utomo, Sutrisno. 2007. Kamus lengkap Jawa-Indonesia. Yogyakarta: Penerbit Kanisius.

Subroto, D. Edi, Soenardji, and Sugiri. 1991. Tata bahasa deskriptifbahasa Jawa. Jakarta: Departemen Pendidikan dan Kebudayaan.

Suhardi, I Dewa Putu Wijana, Sunaryo, and Humam Abu Bakar. 1985. Sistem Sapaan Dalam Bahasa Jawa. Jakarta: Pusat Pembinaan dan Pengembangan Bahasa, Departemen Pendidikan dan Kebudayaan.

Supardo, Susilo. 1995. "Sistem Sapaan Dalam Bahasa Jawa Dialek Banyumas." Tesis, Yogyakarta: Universitas Gadjah Mada. http://etd.repository.ugm.ac.id/home/detail_pencarian/17023. 
Sutoko, Sugianto, Z Sodakoh, and Ayu Soetarto. 1984. Bahasa Jawa di Kabupaten Jember. Jakarta: Direktorat Jenderal Kebudayaan, Departemen Pendidikan dan Kebudayaan.

Uhlenbeck, Eugenius Marius. 1982. Kajian morfologi bahasa Jawa. Jakarta: Djambatan.

Wardhaugh, Ronald. 1986. An Introduction to Sociolinguistics. Oxford: Blackwell.

Wijana, I Dewa Putu. 2008. "Register Sabung Ayam Di Bal." In Kelana Bahana Sang Bahasawan, edited by Katharina Endriati Sukamto, 477-503. Jakarta: Universitas Atma Jaya.

—. 2014. "Kata-Kata Kasar Dalam Bahasa Jawa." In Bunga Rampai Persoalan Linguistik, Sosiolinguistik, Dan Pragmatik, 79-98. Yogyakarta: A Com Press.

\section{LAMPIRAN}

Daftar Kognat Bahasa Jawa dan Bali (A dan B)

\begin{tabular}{|c|c|c|}
\hline Bahasa Jawa & Bahasa Bali & Gloss \\
\hline aba $\approx$ & baæ & merah, register $(\mathrm{Bl})$ \\
\hline abiyoso & bias $\partial$ & biasa \\
\hline abon & abon & abon, daging sayat \\
\hline abot, awrat & baat & berat \\
\hline adə? & $\operatorname{ad\partial g}$ & berdiri, keadaan berdiri \\
\hline adhi & adhi & adik \\
\hline adhu? & adhu? & aduk \\
\hline adityo & adity & matahari, ragam sastra \\
\hline adoh & joh & jauh \\
\hline adu & adu & adu \\
\hline adus & mandus & mandi \\
\hline$a \varpi n g$ & $a \nsubseteq n g$ & aneh $><\operatorname{seram}(\mathrm{BI})$ \\
\hline $\operatorname{ag} \partial \approx$ & $\operatorname{ag} \partial \otimes$ & besar \\
\hline ajah & ajah & ajar \\
\hline aja? & aja? & ajak \\
\hline ajar & ajah & ajar \\
\hline ajrih & jerih & takut $><$ takut untuk ayam \\
\hline$a k \cdot h$ & $a k \varpi h$ & banyak, biasa $><$ halus \\
\hline alap & alap & petik, terbatas <> luas \\
\hline alas & alas & hutan \\
\hline alls & alis & alis \\
\hline allt & allt & kecil, Bl, Jw halus. \\
\hline alu & lu & antan \\
\hline alum & lum-lum & layu \\
\hline alUs & alUs & halus \\
\hline aluwUะ & $\operatorname{luU}$ & bagus, sastra $<>$ biasa \\
\hline ambah & ambah & Ialu \\
\hline
\end{tabular}


Kognat Bahasa Jawa dan Bahasa Bali: Sebuah Studi Kontrastif

\begin{tabular}{|c|c|c|}
\hline amerto & mertə & hidup \\
\hline ampa\& & ampa® & ringan \\
\hline ampas & ampas & sisa \\
\hline ampo & ampo & tanah liat digoreng \\
\hline anak & panak & anak \\
\hline ancak & ancak & anyaman bamboo \\
\hline anca: & anca: & persiapan \\
\hline andh $\partial \notin$-andh $\partial \notin$ & 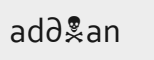 & tahi lalat \\
\hline andum & dum & bagi, sastra $><$ biasa \\
\hline anem, nom & anom & muda $(J w)><$ dewasa $(B I)$ \\
\hline$a \notin \partial t$ & $a \circledast \partial t$ & hangat \\
\hline$a \approx g e$ & $\mathrm{a} \otimes \mathrm{ge}$ & pakai \\
\hline$a \neq g o$ & $\mathrm{a} * \mathrm{go}$ & pakai \\
\hline$a * i n$ & a in & angin \\
\hline o*ko & $\mathrm{a} \otimes \mathrm{k} \partial$ & angka \\
\hline$a \notin k o r o$ & $\mathrm{a} \nsim$ kard & \\
\hline$a * 10$ & $\mathrm{a} \otimes \mathrm{x}^{2}$ & angkara \\
\hline$a * 0 n$ & a:̊n & tungku \\
\hline anjl: & ranjl: & menggembalakan \\
\hline anom & anom & masuk \\
\hline antigo & tiga, telu & muda $><$ dewasa \\
\hline antos & anthos & telur \\
\hline ард? & ард? & tunggu, Bl dan Jw halus \\
\hline api & api & berbau tidak sedap \\
\hline aplt & aplt & api, terbatas $><$ luas \\
\hline apuro & ampurə & apit \\
\hline aran & aran & maaf \\
\hline $\operatorname{arco}$ & $\operatorname{arc\partial }$ & nama, biasa $><$ sastra \\
\hline $\operatorname{ar} n$ & $\operatorname{ar} \boxplus n$ & patung, luas $><$ terbatas \\
\hline $\operatorname{ard} x_{x}$ & adz & aren \\
\hline $\operatorname{ar} s$ & $\operatorname{ar} s$ & arang \\
\hline $\operatorname{arlp}$ & arlp & pangkal $><$ seluruh batang \\
\hline aslh & aslh & mengantuk \\
\hline asri & asri & kasih \\
\hline asu & asu & indah \\
\hline awa? & awag & anjing, kasar $><$ halus \\
\hline ati & ati & ngawur \\
\hline
\end{tabular}




\begin{tabular}{|c|c|c|}
\hline atos & kathos & hati \\
\hline awa? & awa? & keras \\
\hline awit & kawit & badan \\
\hline ayam & ayam & awal (B| terbatas) \\
\hline ayan & ayan & ayam, biasa $><$ halus \\
\hline ayu & ayu & epilepsi \\
\hline babat & babad & cantik, biasa $><$ halus \\
\hline baba? & baba? & cerita $><$ membeberkan \\
\hline Babi & Babi & lecet \\
\hline badho* & badhว & babi, biasa $><$ halus halus \\
\hline bagawan & bəgawan & hiasan dada \\
\hline bagdblu? & gerubug & pendeta \\
\hline bagUs & bagUs & wabah \\
\hline baju & baju & tampan \\
\hline bojro & bajrd & pakaian \\
\hline bakUะ & bakU® & tombak bermata lima $><$ genta \\
\hline balabar & bdlabar & \\
\hline Bagdblu? & gerubug & nama bunga \\
\hline balonjo & bəlanjд & tumpah, mengalir $><$ banjir \\
\hline bale & bale & wabah \\
\hline banci & banclh & belanja \\
\hline bəะal & bəશal & rumah $><$ dipan, tempat tidur \\
\hline ba*ke & ba※ke & banci \\
\hline baœcol & baøcol & Bengal \\
\hline baœu & $\mathrm{ba} \propto u$ & bangkai \\
\hline bopo & bapд & lucu \\
\hline bardt & bardt & air, bersih $><$ kotor \\
\hline barøs & barøs & ayah, sastra $><$ non sastra \\
\hline boto & batว & angin kencang \\
\hline bathoro & 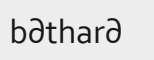 & sederhana $><$ suka memberi \\
\hline bawa* & bawa: & bata \\
\hline bayar & bayah & dewa \\
\hline 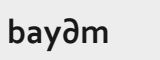 & bayдm & bawang, putih $><$ merah \\
\hline$b \varpi b \varpi ?$ & $\mathrm{~b} \oslash \mathrm{b} \oslash ?$ & bayar \\
\hline$b \varpi b \bullet r$ & $b \cdot r b \cdot r$ & bayam \\
\hline bəcl? & bəci? & bebek. Itik \\
\hline bədhah & bədhah & digelar \\
\hline
\end{tabular}


Kognat Bahasa Jawa dan Bahasa Bali: Sebuah Studi Kontrastif

\begin{tabular}{|c|c|c|}
\hline bddhawa: & bədhawaæ & bagus \\
\hline 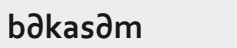 & 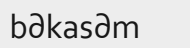 & jebol $><$ robek \\
\hline bəkicot & $\mathrm{b} \partial \mathrm{k}=\mathrm{cot}$ & penyu \\
\hline bəાдr & bəાдr & telur asin \\
\hline bənah & bdnah & keong \\
\hline bəndu & bandu & nakal, biasa $><$ kasar \\
\hline $\mathrm{b} \partial * \mathrm{kua} *$ & baækua® & benar \\
\hline bəะo* & 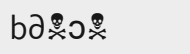 & marah, murka \\
\hline bənlÆ & $\mathrm{nl}$ & besusu \\
\hline benjl $\approx$, benja* & benja: & melamun \\
\hline benjo & benjo & jernih \\
\hline bəras, & bəras, baas & besok \\
\hline bərU? & bəru? & tidak bulat \\
\hline bəthok & bdthok & beras. biasa $><$ halus \\
\hline biku & wiku & takaran dari tempurung kelapa \\
\hline biru & biru & sejenis ikan \\
\hline biyang & biyang & pendeta, pertapa \\
\hline blonjo & bəlanjə & \\
\hline bligo & blego & biru, luas $><$ terbatas. \\
\hline bocor & bocor & Ibu, kasar $><$ halus \\
\hline bokor & bokor & belanja \\
\hline bombo: & bombo: & sejenis labu \\
\hline bo $\propto 0 ?$ & bつ $\propto \supset ?$ & bocor \\
\hline boyo & buayd & mundam dari perak \\
\hline brani & bani & besar hati $><$ melatih jago \\
\hline brumbUn & brumbUn & hampir busuk \\
\hline bubu & wuwu & buaya \\
\hline bubur & bubUh & berani \\
\hline buklt, wuklr & buklt & corak bulu ayam \\
\hline bumbu* & bumbUঙ & perangkap ikan \\
\hline bUe & embU® & bubur \\
\hline bu₹kUs & ungkUs & buklt \\
\hline \multirow[t]{4}{*}{ biyUะ } & biyaæ & bumbung \\
\hline & & rebung \\
\hline & & bungkus \\
\hline & & ibu \\
\hline
\end{tabular}

